\title{
Enhancing Osseointegration and Mitigating Bacterial Biofilms on Medical-Grade Titanium with Chitosan- Conjugated Liquid-Infused Coatings
}

\author{
Yuxi Zhang \\ McMaster University \\ Martin Villegas \\ McMaster University \\ Maryam Badv \\ McMaster University \\ Claudia Alonso-Cantu \\ McMaster University \\ David Wilson \\ Juravinski Hospital \\ Zeinab Hosseinidoust \\ McMaster University \\ Tohid F. Didar ( $\nabla$ didar@mcmaster.ca ) \\ McMaster University
}

\section{Research Article}

Keywords: Titanium alloys, in particular, medical-grade Ti-6Al-4V, LIS, MRSA, extracellular matrix (ECM)

Posted Date: June 18th, 2021

DOI: https://doi.org/10.21203/rs.3.rs-624942/v1

License: (c) (i) This work is licensed under a Creative Commons Attribution 4.0 International License. Read Full License 


\section{Abstract}

Titanium alloys, in particular, medical-grade Ti-6Al-4V is heavily used in orthopaedic applications due to its high moduli, strength, and biocompatibility. Implant infection can result in biofilm formation and failure of prosthetics. The formation of a biofilm on implants protect bacteria from antibiotics and the immune response, resulting in the propagation of the infection and ultimately result in device failure. Recently, slippery liquid-infused surfaces (LIS) have been investigated for their stable liquid interface, which provide excellent repellent properties to suppress biofilm formation. One of the current limitations of LIS coatings lies in the indistinctive repellency of bone cells in orthopaedic applications, therefore causing poor integration between tissue and implant. Here, we report a chitosan impregnated LIS coating that facilitates cell adhesion and osseointegration while preventing biofilm formation. Our results indicate that chitosan-conjugated LIS increased cell adhesion of osteoblast-like SaOS-2 cells and significantly promoted proliferation compared to conventional titanium liquid-infused surfaces. Furthermore, the chitosan conjugated LIS significantly reduced biofilm formation of methicillin-resistant Staphylococcus aureus (MRSA) when compared to untreated and chitosan-coated titanium. Our engineered coating can be easily modified with other biopolymers or capture molecules to be applied to other biomaterials where both tissue integration and biofilm prevention is needed.

\section{Introduction}

Indwelling medical implants are highly susceptible to bacterial infections, in particular $S$. aureus and coagulase-negative staphylococci, account for 50 to 60 percent of total prosthetic joint infections. ${ }^{1}$ In most cases, the bacteria will form a biofilm on the implant surface. A bacterial biofilm is a surface-associated community enclosed in an extracellular matrix (ECM). The ECM is a self-secreted polymer composed of glycoproteins, extracellular DNA, and polysaccharides; it promotes bacterial adhesion, increases communication between bacteria, and protects the bacterial community. ${ }^{2-5}$ Eradicating biofilms from a medical device can be very challenging, partially because bacterial biofilms provide protection from the immune system and antibiotics. Moreover, bacteria in the biofilm can be up to $1000 \mathrm{X}$ more resistant to antibiotics than planktonic bacteria, ${ }^{6}$ leaving no option but to remove the infected implant through multiple surgeries. Prosthetic joint infection is the leading cause of hip and knee revision surgeries in North America, accounting for $34 \%$ of the total knee revision surgeries in Canada ${ }^{7}$ and nearly $40 \%$ in the US. ${ }^{8}$ In Canada alone, revision surgeries cost up to 2.3 times the cost of the primary surgery, bringing about an estimated annual cost of $\$ 42.1$ million dollars to the Canadian healthcare system. ${ }^{7}$

In recent years, innovations in material science and surface engineering have led to new strategies to prevent biofouling. Among them, liquid-infused surfaces (LIS) inspired by Nepenthes pitcher plants have become increasingly popular due to their excellent repellent properties. ${ }^{9-11}$ LIS coatings are composed of a lubricating layer, which is tethered to the substrate of interest via chemical and topographical means. ${ }^{9}$ The lubricating liquid is chosen to be immiscible with other liquids, thus creating a repellent layer that prevents interactions with the underlying substrate. Furthermore, these coatings are commonly described as slippery due to their characteristic low water sliding angles $\left(<5^{\circ}\right) \cdot{ }^{9}$ LIS coatings can be very effective in creating antifouling surfaces for medical implants, ${ }^{10-15}$ and can be easily integrated into many material types, including metals such as stainless steel ${ }^{16}$ and titanium. ${ }^{17}$

Preventing implant failure, however, is not limited to preventing contamination and mitigating biofilm formation; the implant has to integrate with the surrounding tissue. This is especially important for load-bearing applications, as insufficient interlocking can cause stress-shielding and promote bone loss, which could result in device loosening. In Canada, aseptic loosening is the second leading cause for revision surgeries, accounting for $17 \%$ of total knee and hip revisions. ${ }^{18}$ Several biopolymers and biocompatible coatings have been reported as coatings on orthopaedic implants to promote osseointegration. ${ }^{19-21}$ Chitosan is a notable example and has been reported to induce the proliferation of

Loading [MathJax]/jax/output/CommonHTML/fonts/TeX/fontdata.js ion in vivo. ${ }^{22}$ Furthermore, chitosan-coated substrates have been 
reported to have higher elastic moduli than uncoated control surfaces, requiring significantly higher forces to detach osteoblast cells from the coated surface when compared with bare substrates. ${ }^{23}$

In the past few years, our lab has created several biofunctional liquid-infused surfaces. For example, biofunctional LIS on vascular grafts prevented biofouling and thrombin generation while enhancing endothelialization, ${ }^{12-15}$ or containing antibiotics as a fail-safe biofilm protection layer. ${ }^{24}$ In these studies we have shown that a biofunctional coating where the repellency properties and tissue integration can be achieved, without compromising the LISs' repellency properties. However, most of the previous work has focused on (semi)permeable substrates and not monolithic hard substrates, like titanium, that are the material of choice for orthopaedic applications.

In this work, we set out to create a new generation of biofunctional liquid-infused coatings on titanium alloy with high osteoblast affinity to promote cell and tissue attachment and proliferation without compromising the antifouling properties of the liquid-infused layer. This was achieved by incorporating a chitosan conjugated liquid-infused surface coating on a medical-grade titanium alloy. Titanium alloys are widely used in biomedical implants due to their high moduli, strength, ${ }^{25}$ and biocompatibility, ${ }^{26}$ as well as their high resistance to degradation, wear, and fatigue. ${ }^{27}$ The developed coating combines chitosan for osteointegration and LIS for repelling bacterial adhesion. We conceptualize a modular coating with the superior antifouling properties of LIS which can be modified with different capture molecules for tissue integration and can be adapted and applied on other materials.

\section{Result And Discussions}

\section{Fabrication of Chitosan Conjugated Lubricant-Infused Titanium.}

Medical grade titanium alloy grade $5\left(\mathrm{Ti}_{6} \mathrm{Al}_{4} \mathrm{~V}\right)$ was functionalized with chitosan and a fluorosilane to create chitosan liquid-infused surfaces (Chitosan-LISs). The fabrication of the biofunctional coating is illustrated in Fig. 1. Briefly, cleaned and dried titanium alloys $(\mathrm{Ti})$ were oxygen-plasma treated to hydroxylate the surfaces, followed by the chemical vapor deposition (CVD) of a mixture of Trichloro $(1 \mathrm{H}, 1 \mathrm{H}, 2 \mathrm{H}, 2 \mathrm{H}$-perfluorooctyl) (TPFS) and 3-Glycidyloxypropyl)trimethoxysilane (GPTMS) silanes for 5 hrs. Mixed silanes where optimized to a ratio of 75:25 for TPFS and GPTMS, respectively. GPTMS is an acrylic silane used to covalently bond chitosan to the surface. ${ }^{28}$ TPFS was chosen due to its high affinity to the perfluoroperhydro phenanthrene (PFPP) lubricant. Maintaining a high TPFS availability is crucial for the liquid-infused coating to remain slippery and repellent. ${ }^{29}$ After CVD of the mixed silanes, unbound silane was removed in a vacuum chamber. Ti samples were then conjugated with chitosan by submerging the samples in a $50 \mu \mathrm{gL}^{-1}$ chitosan solution for $12 \mathrm{hrs}$. at $4{ }^{\circ} \mathrm{C}$. Before testing the samples, substrates were acclimated to room temperature, and lubricated with $80 \mu \mathrm{L}$ of PFPP to produce the Chitosan-LIS coating.

Surfaces were characterized using contact angle (CA) and sliding angle (SA) measurements. Contact angles were obtained using an optical goniometer (OCA20), adding $2 \mu \mathrm{L}$ droplets of Milli-Q water on control samples (titanium alloy (Ti), TPFS modified titanium (Ti-FS), chitosan conjugated titanium (Chitosan)), and experimental group (TPFS chitosan conjugated Ti (Chitosan-FS)). As seen in Fig. 2a, treated and untreated substrates exhibit different wetting properties. Titanium is naturally hydrophilic, displaying contact angles of $86.4 \pm 2.7^{\circ}$. In contrast, Ti-FS treated surfaces were highly hydrophobic, displaying a mean contact angle of $123.2 \pm 7.4^{\circ}$. Similarly, the static water contact angle of chitosan conjugated titanium was highly hydrophilic $\left(39.2 \pm 7.6^{\circ}\right)$, while mixed silanes conjugated samples containing chitosan displayed hydrophobic contact angles $\left(105.9 \pm 12.5^{\circ}\right)$. Although Chitosan-FS samples were more hydrophilic compared with Ti-FS samples (105.9 $\pm 12.5^{\circ}$ and $123.1 \pm 7.4^{\circ}$ respectively), this reduction in hydrophobicity was not statistically significant. Overall, the increased contact angles in samples containing TPFS (Ti-FS and Chitosan-FS) surfaces revealed a successful CVD functionalization process of the TPFS silane.

Loading [MathJax]/jax/output/CommonHTML/fonts/TeX/fontdata.js 
Sliding angles were measured using an off-the-shelf digital angle level. Samples of titanium alloy (Ti), TPFS conjugated titanium (Ti-FS), chitosan conjugated titanium (Chitosan), and mixed chitosan-TPFS functionalized titanium (Chitosan-FS) were tested with and without PFPP lubricant. Briefly, surfaces were mounted onto the digital angle level, secured using double-sided tape, calibrated to the horizontal plane, and then the surfaces were infused with PFPP lubricant (if needed). The excess lubricant was removed by tilting the surfaces 90 degrees for a minute. Once the surfaces were reset to the horizontal position, a $5 \mu \mathrm{L}$ droplet of water was pipetted onto the surfaces. The level was raised slowly, and the sliding angle was obtained at the instance the droplets began to move. The maximum sliding angle given was 90 degrees, and any droplet pinned on the surfaces past the angle of 90 degrees was given the value of 90 . All surfaces lacking a lubricant layer had sliding angles greater than $90^{\circ}$; this included control titanium samples (Ti) as well as chitosan functionalized titanium, fluorosilanized titanium (Ti-FS), and titanium conjugated with TPFS and chitosan (Chitosan-FS). In contrast, lubricated TPFS -titanium samples (Ti-LIS) exhibited slippery properties and a significantly lower sliding angles (3.84 \pm $4.33^{\circ}$ ). Lubricated titanium samples (Ti-Lub) did not slide. In contrast, surfaces that were successfully functionalized with a liquid-infused layer showed water repellency and slippery properties. Interestingly, samples contained both chitosan and TPFS were slippery when lubricated $\left(3.56 \pm 4.32^{\circ}\right)$. These results indicate that adding chitosan to the LIS does not interfere with the slippery properties of LIS, while Ti surfaces lacking proper surface chemistry demonstrated droplet pinning and failed to display slippery properties. Moreover, results showed no significant difference between Ti-LIS and Chitosan-LIS samples, indicating, again, that the liquid-infused coating was not compromised when conjugated with chitosan.

\section{SaOS-2 Cell Adhesion and Viability.}

Mammalian osteoblast-like SaOS-2 osteosarcoma cells were used to model osteoconduction. Cells were cultured for 3 days and 7 days on Ti, Ti-LIS, and Chitosan samples as control groups, and Chitosan-LIS samples as the experimental group. Samples were seeded with $100 \mu \mathrm{L}$ of $8 \times 10^{4}$ cells $\mathrm{mL}^{-1}$ concentration into each well plus an additional $400 \mu \mathrm{L}$ of cell media to cover the samples thoroughly. Well-plates were placed in an incubator at $37{ }^{\circ} \mathrm{C}$ and $5 \% \mathrm{CO}_{2}$, with culture media being changed every three days. Then, substrates were washed, fixed, stained, and imaged using a fluorescence microscope. Figure 3a shows fluorescent images of the cell densities between control and experimental groups. Here, it is evident that conjugated chitosan samples have high cell densities comparable to Ti substrates. Furthermore, when comparing the cell morphology, Ti-LIS samples show a clump of cells in a sphere-like configuration (Fig. 3b).

This could be due to the repellant properties of the LIS coating and the lack of adhesion to the substrate. In contrast, Ti samples and all biofunctionalized surfaces had cells spreading on their surfaces, indicating proper anchoring to the substrate. Cell densities were counted using ImageJ and the results are summarized in Fig. 3c. Chitosan treated surfaces

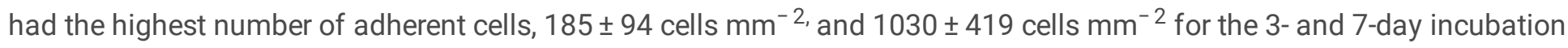
periods, respectively. Chitosan-LIS surfaces displayed cell densities of $140 \pm 37$ cells mm $\mathrm{mm}^{-2}$ and $1133 \pm 270 \mathrm{cells} \mathrm{mm}^{-2}$ after 3-day and 7-day cultures. Cell density on chitosan-LIS, was not statistically different from chitosan substrates or untreated control Ti samples ( $116 \pm 71$ cells $\mathrm{mm}^{-2}$ and $828 \pm 284$ cells $\mathrm{mm}^{-2}$ after 3 and 7 days, Fig. 3c) indicating that impregnating the LIS with chitosan recovers cell adhesion properties of Ti-LIS. As expected, Ti-LIS substrates without chitosan had the lowest number of adherent cells due to their repellant properties, displaying only $56 \pm 71 \mathrm{cells} \mathrm{mm}^{-2}$ after 3 days and $185 \pm 59$ cells $\mathrm{mm}^{-2}$ after 7 days of incubation. On the other hand, Ti-LIS showed a reduced number of adherent cells and were statistically different from chitosan conjugated samples at both time points (Fig. 3c).

\section{Bacteria Repellency Properties and Biofilm Studies.}

The biofunctional Ti coatings were tested against bacterial biofilm formation to evaluate their bacteria repellent properties. Samples of Ti, Ti-LIS, and Chitosan were used as control groups in these experiments and samples of biofunctional liquidinfused surfaces (Chitosan-LIS) were used as the experimental coatings. Briefly, Methicillin-resistant Staphylococcus aureus (MRSA) MW2 strain was incubated in Luria-Bertani medium overnight. The next day, the bacteria were diluted at Loading [MathJax]/jax/output/CommonHTML/fonts/TeX/fontdata.js eloped surfaces in a 48-well plate. The bacteria were incubated 
for $48 \mathrm{hrs}$. at $37^{\circ} \mathrm{C}$ in a shaking incubator at $30 \mathrm{rpm}$. Afterward, the surfaces were washed with PBS, stained with crystal violet (CV), and quantified through light absorbance at $590 \mathrm{~nm}$ using a plate reader.

Biofilm quantities are summarized in Fig. 4, where the CV values are proportional to the biomass created on the fabricated surfaces. A high concentration of biomass was measured on bare Ti samples. In contrast, both Ti-LIS and Chitosan-LIS samples displayed significantly reduced biomass concentrations and exhibited excellent bacteria repellency properties when compared with chitosan treated samples $(P<0.001)$ and $\mathrm{Ti}(\mathrm{P}<0.05)$. In fact, Chitosan-LIS treated samples suppressed bacterial adhesion and biofilm formation to the same extend as liquid-infused modified titanium (Ti-LIS), with crystal violet levels showing no significant difference between these two groups. It is noteworthy that chitosan samples had an increased amount of biomass compared to bare titanium surfaces, even though chitosan is believed to have bactericidal properties. ${ }^{30}$ This might occur due to an increase in surface anchoring sites, and chitosan might still maintain the bactericidal properties below the minimum cytotoxic concentration. Overall, these results demonstrate that chitosan addition did not negatively impacted the antibacterial and blocking properties of the liquid-infused layer, similar to our previously reported biofunctional LIS. ${ }^{15}$ These results align with contact and sliding angle results (Fig. 2), indicating that Chitosan-LIS possesses slippery and repellent properties

\section{Conclusion}

In summary, biofunctional liquid-infused titanium surfaces functionalized with chitosan improved osteoblast-like cell integration and promoted cell proliferation compared to titanium LIS groups. Chitosan within the LIS layer provided anchor points for cells to spread throughout the titanium device, and no significant difference was seen when compared to substrates coated with chitosan alone. Methicillin-resistant $S$. aureus biofilm experiment demonstrated a significantly reduced biomass adhesion on Chitosan-LIS comparable to traditional liquid-infused coated titanium surfaces, indicating suppression of biofilm formation on these surfaces. Furthermore, the contact angle, sliding angle, and biofouling results indicate a functional liquid-infused coating on the biofunctional LIS samples. We hypothesize that this fabrication process can be easily adapted for other materials, like cobalt-chromium alloy, carbon fiber, aluminum oxide, and ceramics used in the orthopaedic field. This coating can be used to prevent the formation of biofilms and promote osteoconductive properties for rapid osseointegration between the implant and the tissue.

\section{Methods}

\section{Materials.}

Titanium alloy (Grade $5, \mathrm{Ti}_{6} \mathrm{Al}_{4} \mathrm{~V}$ ) sheets $(1.6 \mathrm{~mm} \times 30.5 \mathrm{~cm} \times 30.5 \mathrm{~cm})$ were purchased from McMaster-CARR USA (www.mcmaster.com) and cut by CIM Metals (www.cimmetals.com) into $7 \mathrm{~mm}$ diameter discs using water jet. Trichloro $(1 \mathrm{H}, 1 \mathrm{H}, 2 \mathrm{H}, 2 \mathrm{H}$-perfluorooctyl) silane (TPFS) 97\%, perfluoroperhydrophenanthrene (PFPP), (3Glycidyloxypropyl)trimethoxysilane (GPTMS) 98\%, Triton ${ }^{T M}$ X-100 Surfact-Amps ${ }^{T M}$ Detergent Solution, phosphate buffered saline (PBS), bovine serum albumin (BSA), penicillin/streptomycin, medium molecular weight chitosan and fetal bovine serum (FBS) were purchased from Sigma - Aldrich (Oakville, Canada). McCoy's 5A modified medium, Trypsin-EDTA (0.25\%), methanol-free formaldehyde, and DAPI (4',6-diamidino-2-phenylindole) were purchased from Thermo Fisher Scientific (Waltham, MA, USA). Phalloidin FITC Reagent was purchased from Abcam (abcam.com).

\section{Preparation of Liquid-Infused Coating on Titanium Substrates.}

Titanium samples were cleaned with acetone, $100 \%$ ethanol, and deionized water in sequence in an ultrasonic bath for 10 min. This sonication step was repeated 3 times with fresh acetone, ethanol, and deionized water. Afterward, samples were dried on a hot plate at $80^{\circ} \mathrm{C}$. Then, titanium samples were placed in a petri dish and placed in an oxygen plasma cleaner 
surfaces. Afterward, plasma-treated substrates were placed in a vacuum chamber alongside a petri dish with TPFS (300 $\mu \mathrm{L}$ ). The chemical vapor deposition (CVD) of TPFS was carried out for $3 \mathrm{hrs}$. at room temperature, followed by an overnight heat treatment at $60^{\circ} \mathrm{C}$ to finish the reaction. After the heat treatment, salinized surfaces were placed inside a vacuum chamber and placed in a vacuum (with the outlet valve open) for $10 \mathrm{~min}$ to remove unbonded silane molecules. Before performing the experiments, PFPP lubricant $(80 \mu \mathrm{L})$ was infused on each sample to create the LIS.

\section{Preparation of Biofunctionalized Liquid-Infused Chitosan Conjugated Coating Using Mixed Silanes.}

Titanium surfaces were cleaned using the steps in the previous procedures. Given that GPTMS can provide anchors for bioconjugation with chitosan and TPFS can maintain repellency of surface, GPTMS and TPFS were used to treat titanium surface during the CVD process. After cleaning the titanium substrates, samples were hydroxylated using oxygen plasma (Harrick Plasma Cleaner, PDC-002, 230 V) for 10 min. After surface activation, samples were placed in a desiccator and CVD treated with a $75 \%-25 \%$ volume ratio of GPTM and TPFS silanes for a total volume of $200 \mu \mathrm{L}$. The silanes were placed on two separate glass slides located adjacent to the samples in the desiccator. The CVD treatment was carried out for $5 \mathrm{hrs}$. followed by an overnight heat treatment at $60{ }^{\circ} \mathrm{C}$ to finish the reaction. Unbonded silane molecules were removed by 10 min post-vacuuming in a desiccator.

A $50 \mu \mathrm{g} \mathrm{ml}^{-1}$ chitosan solution was created by dissolving chitosan in deionized water with $1 \%$ acetic acid by volume solution. The solution was continuously stirred at $600 \mathrm{rpm}$ and heated at $40{ }^{\circ} \mathrm{C}$ for $30 \mathrm{~min}$. Titanium surfaces functionalized with the mixed silanes monolayer were put in a 48 well plate, and chitosan solution $(500 \mu \mathrm{L})$ was added to each well, covering the samples completely. The well plate was kept at $4{ }^{\circ} \mathrm{C}$ for $12 \mathrm{hrs}$. to complete the bioconjugation, after which, samples were washed with PBS and stored at $4{ }^{\circ} \mathrm{C}$ until needed. Before the cell cultivation experiment, samples were moved from the fridge to the incubator, which allowed samples to acclimate to $37^{\circ} \mathrm{C}$. Then, PFPP lubricant $(80 \mu \mathrm{L})$ was added to each sample before performing the experiments.

\section{Contact and Sliding Angle Measurements.}

To investigate the samples' hydrophobicity and slippery properties, a $2 \mu \mathrm{L}$ droplet of Milli-Q water was used to perform static contact angle measurements. Contact angle measurements were performed on a Future Digital Scientific OCA20 goniometer (Garden City, NY) at room temperature. A minimum of three samples were tested for each group.

The sliding angles were measured using a digital angle level (ROK, Exeter, UK). The apparatus was first calibrated to a horizontal leveled surface, then, samples were placed on the apparatus followed by the addition of PFPP lubricant. The excess lubricant was removed by tilting the samples vertically for a minute. Once repositioned, a $5 \mu \mathrm{L}$ droplet of deionized water was placed on the lubricated samples. The tilting stage was raised gently, and the sliding angle was taken as the smallest angle of inclination when the droplet started to slide. If the droplet failed to slide past the angle of 90 degrees, the sliding angle was recorded as a maximum of 90 degrees. The measurements were repeated 3 times on each sample, and a minimum of three samples were used in each group tested.

\section{Cell Density Testing of Modified Titanium Surfaces.}

SaOS-2 osteosarcoma cells $\left(\right.$ ATCC $^{\circledR}$ ) were cultured in mixed McCoy's modified 5A media supplemented with $15 \%$ fetal bovine serum (FBS) and 1\% penicillin/streptomycin. SaOS-2 cells were cultivated in an incubator at $37{ }^{\circ} \mathrm{C}$ and $5 \% \mathrm{CO}_{2}$, with their media being changed every 3 days. When cells became confluent, cells were detached using Trypsin-EDTA and diluted to a specific concentration for in-vitro studies. Modified surfaces without lubricant, LIS modified titanium, and untreated titanium samples were used as control groups, while chitosan-LIS conjugated samples were taken as the

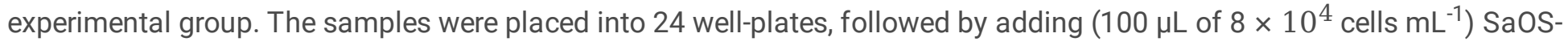
2 in media to each well (concentration was counted by hemocytometer). Afterward, $400 \mu \mathrm{L}$ cell media was added to each

Loading [MathJax]/jax/output/CommonHTML/fonts/TeX/fontdata.js it in an incubator at $37^{\circ} \mathrm{C}$ with cell media changed every 5 days. 
After culturing for a specific culture time (3 or 7 days), samples were washed with PBS twice to remove unattached cells. Adherent cells were fixed, permeabilized, and blocked using 4\% formalin, 0.1\% Triton X-100 and 4\% BSA solution, respectively. Finally, DAPI and phalloidin solutions were used to stain the cell nuclei and actin filaments. The surfaces were imaged with a fluorescence microscope to evaluate the cell's density and morphology. The concentration of cell adhesion and proliferation of each sample was calculated using Image J software. Each group had at least 3 samples and 3 images per sample were used for ImageJ analysis. The quantification of cell density on each sample was calculated by dividing the total number of cells by the sample's surface area in the image.

\section{Biofilm Formation.}

Biofilms were grown on surfaces to test the biofilm formation, and adhered biomass was visualized by crystal violet staining using Staphylococcus aureus strain MW2. In each type of surface, 2 samples were used as blank. S. aureus was first cultured in Luria-Bertani medium (LB) overnight. Then, Bacteria were diluted at 1:100 bacteria in fresh media and cultured for $2.5 \mathrm{hrs}$. until it reached $\sim \mathrm{OD}_{600}=0.4$, measured by plate reader. Then bacteria were seeded with TSBC5 media (Tryptic Soy broth with $0.5 \%$ glucose, $0.2 \%$ sodium citrate, $0.6 \%$ yeast extract) at a $1: 50$ ratio and added to a 48 well-plate covering the samples completely. $35 \mu \mathrm{L}$ mixed solution was put in each well and incubated at $37{ }^{\circ} \mathrm{C}$ in a shaking incubator at $30 \mathrm{rpm}$. After a 48-hr bacteria culture with $S$. aureus, samples were gently washed in PBS solution and put into a clean 24 well-plate. Then, crystal violet $(\mathrm{CV})(700 \mathrm{~mL})$ was added for $15 \mathrm{~min}$ to stain the samples. Excess CV was removed by a series of wash using DI water until the removed water appeared clear from CV. Samples were allowed to air-dry overnight at room temperature. The next morning, acetic acid $(700 \mu \mathrm{L}$ of $30 \%)$ was added into each well for 20 min, allowing the $\mathrm{CV}$ to dissolve into the acid solution completely. Solutions were mixed with the pipette. Once the solution was homogeneously mixed, $250 \mu \mathrm{L}$ solution were transferred to a 96 well-plate. The absorbance of CV was measured at $590 \mathrm{~nm}$ using a microplate spectrophotometer (Bio-Rad Laboratories, CA, USA). Finally, optical density results obtained from CV light absorption on experimental groups were subtracted by absorption levels of the blank samples (cultured without bacteria).

\section{Statistical Analysis.}

All statistical analyses were performed using the open-source software R, version 3.3.2 (www.r-project.org). Nonparametric data were tested with Kruskal-Wallis Rank Sum Test from the R package stats version 3.3.2, followed by a multiple comparison test from $\mathrm{R}$ package pgirmess version 1.6.5. Parametric data were tested using an ANOVA followed by a posthoc Tukey test. Significance levels were defined as significant ' $*$ ' at $p$-values of $<0.05$, highly significant ' $* \star^{\prime}$ at $p$-values

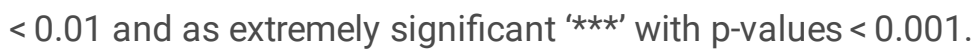

\section{Declarations}

\section{Acknowledgements}

This work was supported by the Natural Sciences and Engineering Research Council of Canada (NSERC) Discovery Grant, Ontario Early Researcher Award Grant, and McMaster start-up funds to T. F. Didar and (NSERC) Discovery Grant for Z. Hosseinidoust.

Author's Contribution

T. F. D. and Z. HD. conceived the research and supervised the experiments. Y.Z., M. V., C. A-C. and M. B. performed all experiments with the supervision of T. F. D. and Z. HD. M.V. wrote the manuscript with contributions from all authors. All the authors have read, commented, and approved the final version of the paper.

\section{Competing interests}

Loading [MathJax]/jax/output/CommonHTML/fonts/TeX/fontdata.js 
The authors declare no competing interests.

\section{References}

1. Tande, A. J. \& Patel, R. Prosthetic joint infection. Clin. Microbiol. Rev. 27, 302-345 (2014).

2. Seth, A. K. et al. In vivo modeling of biofilm-infected wounds: A review. Journal of Surgical Research 178, 330-338 (2012).

3. Zapotoczna, M., O’Neill, E. \& O'Gara, J. P. Untangling the Diverse and Redundant Mechanisms of Staphylococcus aureus Biofilm Formation. PLoS Pathogens 12, (2016).

4. Lewis, K. Persister Cells. Annu. Rev. Microbiol. 64, 357-372 (2010).

5. Roy, R., Tiwari, M., Donelli, G. \& Tiwari, V. Strategies for combating bacterial biofilms: A focus on anti-biofilm agents and their mechanisms of action. Virulence 9, 522-554 (2018).

6. Rasmussen, T. B. \& Givskov, M. Quorum-sensing inhibitors as anti-pathogenic drugs. Int. J. Med. Microbiol. 296, 149-161 (2006).

7. Early Revisions of Hip and Knee Replacements in Canada: A Quality, Productivity and Capacity Issue. (2020).

8. D'Onofrio, K. Infection Most Common Culprit of Revision TKA Failure. (2020). Available at:

https://www.aaos.org/aaosnow/2020/aaos-now-special-edition/research/557_knee/. (Accessed: 11th November 2020)

9. Villegas, M., Zhang, Y., Abu Jarad, N., Soleymani, L. \& Didar, T. F. Liquid-Infused Surfaces: A Review of Theory, Design, and Applications. ACS Nano 13, (2019).

10. Howell, C., Grinthal, A., Sunny, S., Aizenberg, M. \& Aizenberg, J. Designing Liquid-Infused Surfaces for Medical Applications: A Review. Adv. Mater. 1802724 (2018). doi:10.1002/adma.201802724

11. Sotiri, I., Overton, J. C., Waterhouse, A. \& Howell, C. Immobilized liquid layers: A new approach to anti-adhesion surfaces for medical applications. Exp. Biol. Med. 241, 909-918 (2016).

12. Badv, M., Jaffer, I. H., Weitz, J. I. \& Didar, T. F. An omniphobic lubricant-infused coating produced by chemical vapor deposition of hydrophobic organosilanes attenuates clotting on catheter surfaces. Sci. Rep. 7, 11639 (2017).

13. Badv, M., Imani, S. M., Weitz, J. I. \& Didar, T. F. Lubricant-Infused Surfaces with Built-In Functional Biomolecules Exhibit Simultaneous Repellency and Tunable Cell Adhesion. ACS Nano 12, 10890-10902 (2018).

14. Badv, M., Weitz, J. I. \& Didar, T. F. Lubricant-Infused PET Grafts with Built-In Biofunctional Nanoprobes Attenuate Thrombin Generation and Promote Targeted Binding of Cells. Small 15, 1905562 (2019).

15. Badv, M. et al. Biofunctional Lubricant-Infused Vascular Grafts Functionalized with Silanized Bio-Inks Suppress Thrombin Generation and Promote Endothelialization. ACS Biomater. Sci. Eng. 5, 6485-6496 (2019).

16. Zhang, P., Chen, H., Zhang, L. \& Zhang, D. Anti-adhesion effects of liquid-infused textured surfaces on hightemperature stainless steel for soft tissue. Appl. Surf. Sci. 385, 249-256 (2016).

17. Doll, K. et al. Development of Laser-Structured Liquid-Infused Titanium with Strong Biofilm-Repellent Properties. ACS Appl. Mater. Interfaces 9, 9359-9368 (2017).

Loading [MathJax]/jax/output/CommonHTML/fonts/TeX/fontdata.js 
18. Hip and Knee Replacements in Canada: CJRR Annual Statistics Summary, 2018-2019. (2020).

19. Agarwal, R. \& García, A. J. Biomaterial strategies for engineering implants for enhanced osseointegration and bone repair. Advanced Drug Delivery Reviews 94, 53-62 (2015).

20. Shi, S. et al. RhBMP-2 Microspheres-Loaded Chitosan/Collagen Scaffold Enhanced Osseointegration: An Experiment in Dog. Biomater. Appl. 23, (2009).

21. Li, X. et al. Osseointegration of chitosan coated porous titanium alloy implant by reactive oxygen species-mediated activation of the PI3K/AKT pathway under diabetic conditions. Biomaterials 36, 44-54 (2015).

22. Costa-Pinto, A. R., Reis, R. L. \& Neves, N. M. Scaffolds based bone tissue engineering: The role of chitosan. Tissue Eng. - Part B Rev. 17, 331-347 (2011).

23. Moutzouri, A. G. \& Athanassiou, G. M. Insights into the alteration of osteoblast mechanical properties upon adhesion on chitosan. Biomed Res. Int. 2014, 1-8 (2014).

24. Villegas, M. et al. Antibiotic-Impregnated Liquid-Infused Coatings Suppress the Formation of Methicillin-Resistant Staphylococcus aureus Biofilms. ACS Appl. Mater. I\& Interfaces $\mathbf{0}$, null

25. Khorasani, A. M., Goldberg, M., Doeven, E. H. \& Littlefair, G. Titanium in biomedical applications-properties and fabrication: A review. Journal of Biomaterials and Tissue Engineering 5, 593-619 (2015).

26. Sidambe, A. T. Biocompatibility of advanced manufactured titanium implants-A review. Materials 7, 8168-8188 (2014).

27. Boehlert, C. J., Cowen, C. J., Quast, J. P., Akahori, T. \& Niinomi, M. Fatigue and wear evaluation of Ti-Al-Nb alloys for biomedical applications. Mater. Sci. Eng. C 28, 323-330 (2008).

28. Ruini, F., Tonda-Turo, C., Chiono, V. \& Ciardelli, G. Chitosan membranes for tissue engineering: comparison of different crosslinkers. Biomed. Mater. 10, 065002 (2015).

29. Schellenberger, F. et al. Direct observation of drops on slippery lubricant-infused surfaces. Soft Matter 11, 76177626 (2015).

30. Shi, Z., Neoh, K. G., Kang, E. T., Poh, C. \& Wang, W. Bacterial adhesion and osteoblast function on titanium with surface-grafted chitosan and immobilized RGD peptide. J. Biomed. Mater. Res. Part A 86A, 865-872 (2008).

\section{Tables}

Table 1. Key characteristics of P- and K-hydrogels. 


\begin{tabular}{|c|c|c|}
\hline Parameter & P-hydrogel & K-hydrogel \\
\hline Chemical constitution & $\begin{array}{l}\text { Derivatized cellulose based grafted } \\
\text { and crosslinked anionic polyacrylate }\end{array}$ & $\begin{array}{l}\text { Derivatized cellulose based grafted and } \\
\text { crosslinked anionic polyacrylate incorporating } \\
\text { kaolin }\end{array}$ \\
\hline Appearance & Amorphous white/yellow granules & Amorphous brownish granules \\
\hline Particle size & 20-100 mesh (micro granules) & 20-100 mesh (micro granules) \\
\hline $\mathrm{pH}$ & $7.0-7.5$ & $7.0-7.5$ \\
\hline Stability at $50^{\circ} \mathrm{C}$ & Stable & Stable \\
\hline Sensitivity to UV light & Not sensitive & Not sensitive \\
\hline $\begin{array}{l}\text { Maximum absorption in } \\
\text { deionized water }\left(50^{\circ} \mathrm{C}\right)\end{array}$ & $350 \mathrm{~g} / \mathrm{g}$ & $600-800 \mathrm{~g} / \mathrm{g}$ \\
\hline $\begin{array}{l}\text { Temperature of } \\
\text { maximum absorption }\end{array}$ & $50^{\circ} \mathrm{C}$ & $50^{\circ} \mathrm{C}$ \\
\hline $\begin{array}{l}\text { Time taken for } 60 \% \\
\text { swelling }\end{array}$ & 2 h (approximately) & 4 h (approximately) \\
\hline Stability in soil & $\begin{array}{l}\text { Less than } 2 \text { years (anticipated based } \\
\text { on } \\
\text { available literature) }\end{array}$ & $\begin{array}{l}\text { Less than } 2 \text { years (anticipated based on } \\
\text { available literature) }\end{array}$ \\
\hline Toxicity in soil & None under normal conditions & None under normal conditions \\
\hline
\end{tabular}

Table 2. Agronomic practices followed and inputs applied during 2017-2019 in soybean-wheat system.

\begin{tabular}{|lll|}
\hline $\begin{array}{l}\text { Agronomic } \\
\text { practice }\end{array}$ & Soybean (2017 and 2018) & Wheat (2017-18 and 2018-19) \\
\hline $\begin{array}{l}\text { Variety/hybrid } \\
\begin{array}{l}\text { Seed rate } \\
\text { (kg/ha) }\end{array}\end{array}$ & PS 1347 & HD 3086 \\
\hline $\begin{array}{l}\text { Dates of } \\
\text { sowing }\end{array}$ & $15-07-2017 ; 09-07-2018$ & 100 \\
\hline Net plot size & $3.6 \times 2.5 \mathrm{~m}=9.0 \mathrm{~m}^{2}$ & $22-11-2017 ; 26-11-2018$ \\
\hline $\begin{array}{l}\text { Fertilizers } \\
\text { (kg/ha) }\end{array}$ & $60: 80: 40: 20$ NPKS & $3.6 \times 2.5 \mathrm{~m}=9.0 \mathrm{~m}^{2}$ \\
\hline $\begin{array}{l}\text { Weed } \\
\text { management }\end{array}$ & $\begin{array}{l}\text { Pre-emergence: Pendimethalin @ 0.75 kg a.i., } 1 \\
\text { hand weeding at 40 DAS }\end{array}$ & $\begin{array}{l}\text { Post-emergence: Sulphosulfuron + Metsulphuron } \\
@ 0.075 \text { ml L }{ }^{-1} \text { at 25 DAS }\end{array}$ \\
\hline $\begin{array}{l}\text { Dates of } \\
\text { harvesting }\end{array}$ & $01-11-2017 ; 26-10-2018$ & $17-04-2019 ; 23-04-2019$ \\
\hline
\end{tabular}

Note: D, date; M, Month; Y, year; DAS, days after sowing

Table 3. Effect of hydrogels and moisture stress conditions on yield of soybean and wheat during 2017-18 and 2018-19. 


\begin{tabular}{|c|c|c|c|c|c|c|c|c|c|c|}
\hline \multirow[t]{2}{*}{ Treatment } & \multicolumn{2}{|c|}{$\begin{array}{l}\text { Soybean seed } \\
\text { yield } \\
\left(\mathrm{Mg} \mathrm{ha}^{-1}\right)\end{array}$} & \multicolumn{2}{|c|}{$\begin{array}{l}\text { Soybean } \\
\text { biomass yield } \\
\left(\mathrm{Mg} \mathrm{ha}^{-1}\right)\end{array}$} & \multicolumn{2}{|c|}{$\begin{array}{l}\text { Wheat grain } \\
\text { yield }\left(\mathrm{Mg} \mathrm{ha}^{-1}\right)\end{array}$} & \multicolumn{2}{|c|}{$\begin{array}{l}\text { Wheat biomass } \\
\text { yield }\left(\mathrm{Mg} \mathrm{ha}^{-1}\right)\end{array}$} & \multicolumn{2}{|c|}{$\begin{array}{l}\text { Wheat } \\
\text { equivalent yield } \\
\left(\mathrm{Mg} \mathrm{ha}^{-1}\right)\end{array}$} \\
\hline & 2017 & 2018 & 2017 & 2018 & $\begin{array}{l}2017- \\
18\end{array}$ & $\begin{array}{l}2018- \\
19\end{array}$ & $\begin{array}{l}2017- \\
18\end{array}$ & 2018-19 & $\begin{array}{l}2017- \\
18\end{array}$ & $\begin{array}{l}2018- \\
19\end{array}$ \\
\hline \multicolumn{11}{|c|}{ Irrigation regime (I) } \\
\hline $\begin{array}{l}\text { Full } \\
\text { irrigation }\end{array}$ & $1.16^{\mathrm{a}}$ & $1.22^{\mathrm{a}}$ & $5.31^{\mathrm{a}}$ & $4.81^{a}$ & $4.24^{a}$ & $5.08^{a}$ & $14.90^{\mathrm{a}}$ & $14.81^{\mathrm{a}}$ & $6.03^{a}$ & $7.33^{\mathrm{a}}$ \\
\hline $\begin{array}{l}\text { Limited } \\
\text { irrigation }\end{array}$ & $1.11^{\mathrm{ab}}$ & $1.16^{\mathrm{ab}}$ & $5.05^{a b}$ & $4.79^{a b}$ & $3.52^{b}$ & $4.54^{\mathrm{ab}}$ & $12.90^{\mathrm{b}}$ & $14.20^{\mathrm{b}}$ & $5.29^{b}$ & $6.69^{b}$ \\
\hline Rainfed & $1.05^{\mathrm{c}}$ & $1.12^{\mathrm{c}}$ & $4.72^{\mathrm{bc}}$ & $4.45^{\mathrm{c}}$ & $2.85^{c}$ & $4.09^{c}$ & $9.70^{c}$ & $13.20^{c}$ & $4.56^{c}$ & $6.15^{c}$ \\
\hline \multicolumn{11}{|c|}{ Hydrogel application $(H)$} \\
\hline Control & $1.04^{c}$ & $1.15^{\mathrm{b}}$ & $4.87^{a b}$ & $4.65^{\mathrm{bc}}$ & $3.37^{b}$ & $4.57^{a b}$ & $12.16^{\mathrm{a}}$ & $14.14^{\mathrm{ab}}$ & $4.96^{\mathrm{bc}}$ & $6.70^{a}$ \\
\hline $\begin{array}{l}\text { K-hydrogel } \\
\text { @ } 2.5\end{array}$ & $1.11^{\mathrm{b}}$ & $1.15^{\mathrm{bc}}$ & $4.76^{\mathrm{bc}}$ & $4.35^{\mathrm{cd}}$ & $3.54^{b}$ & $4.42^{\mathrm{bcd}}$ & $12.73^{\mathrm{a}}$ & $14.09^{a b c}$ & $5.27^{b}$ & $6.54^{a}$ \\
\hline $\begin{array}{l}\text { K-hydrogel } \\
\text { @ } 5.0\end{array}$ & $0.98^{d}$ & $1.14^{\mathrm{bcd}}$ & $5.06^{a b}$ & $4.87^{\mathrm{ab}}$ & $3.36^{\mathrm{bc}}$ & $4.56^{a b c}$ & $12.22^{\mathrm{a}}$ & $13.78^{\mathrm{cd}}$ & $4.86^{\mathrm{cd}}$ & $6.67^{a}$ \\
\hline $\begin{array}{l}\text { P-hydrogel } \\
\text { @ } 2.5\end{array}$ & $1.30^{\mathrm{a}}$ & $1.22^{\mathrm{a}}$ & $5.40^{a}$ & $4.88^{a}$ & $3.88^{a}$ & $4.73^{\mathrm{a}}$ & $12.89^{a}$ & $14.28^{a}$ & $6.09^{a}$ & $6.99^{a}$ \\
\hline \multicolumn{11}{|l|}{ Ix H effect } \\
\hline Fl+Control & $1.24^{\mathrm{cd}}$ & $1.24^{\mathrm{a}}$ & $5.82^{\mathrm{ab}}$ & $5.23^{a}$ & $3.78^{c}$ & $4.81^{c}$ & $13.53^{c}$ & $14.04^{\mathrm{cd}}$ & $5.67^{\mathrm{bc}}$ & $7.10^{b}$ \\
\hline $\begin{array}{l}\text { Fl+K-gel @ } \\
2.5\end{array}$ & $1.07^{f}$ & $1.18^{\mathrm{ab}}$ & $4.65^{\mathrm{cd}}$ & $4.38^{c}$ & $4.33^{a b}$ & $5.07^{a b c}$ & $15.40^{\mathrm{ab}}$ & $15.02^{a b}$ & $5.92^{b}$ & $7.25^{a b}$ \\
\hline $\begin{array}{l}\text { Fl+K-gel @ } \\
5.0\end{array}$ & $0.94^{\mathrm{gh}}$ & $1.19^{a b}$ & $4.91^{\mathrm{cd}}$ & $4.67^{\mathrm{ab}}$ & $4.39^{a b}$ & $5.11^{\mathrm{ab}}$ & $15.04^{\mathrm{ab}}$ & $14.67^{b}$ & $5.76^{b}$ & $7.31^{a b}$ \\
\hline $\begin{array}{l}\text { Fl+P-gel @ } \\
2.5\end{array}$ & $1.37^{a}$ & $1.26^{a}$ & $5.85^{a}$ & $4.97^{\mathrm{ab}}$ & $4.47^{a}$ & $5.34^{a}$ & $15.63^{a}$ & $15.53^{a}$ & $6.77^{a}$ & $7.67^{a}$ \\
\hline LI+Control & $1.07^{\mathrm{ef}}$ & $1.25^{a}$ & $5.41^{\mathrm{ab}}$ & $5.02^{a b}$ & $3.59^{\mathrm{cd}}$ & $4.59^{\mathrm{de}}$ & $13.51^{\mathrm{c}}$ & $14.71^{b}$ & $5.24^{\mathrm{cd}}$ & $6.91^{b c}$ \\
\hline $\begin{array}{l}\text { LI+K-gel @ } \\
2.5\end{array}$ & $1.29^{c}$ & $1.07^{c}$ & $5.03^{\mathrm{cd}}$ & $4.63^{a b}$ & $3.32^{d}$ & $4.19^{e f}$ & $12.73^{\mathrm{cd}}$ & $14.24^{\mathrm{c}}$ & $5.36^{c}$ & $6.16^{\mathrm{ef}}$ \\
\hline $\begin{array}{l}\text { LI+K-gel @ } \\
5.0\end{array}$ & $0.84^{\mathrm{hi}}$ & $1.14^{b}$ & $4.65^{\mathrm{cd}}$ & $4.86^{a b}$ & $3.24^{d}$ & $4.75^{\mathrm{cd}}$ & $12.45^{\text {de }}$ & $13.86^{\text {cde }}$ & $4.55^{\mathrm{e}}$ & $6.84^{\mathrm{cd}}$ \\
\hline $\begin{array}{l}\text { LI+P-gel @ } \\
2.5\end{array}$ & $1.22^{\mathrm{b}}$ & $1.19^{a b}$ & $5.11^{c d}$ & $4.67^{a b}$ & $3.94^{\mathrm{bc}}$ & $4.63^{d}$ & $12.93^{c}$ & $14.00^{\mathrm{cd}}$ & $6.03^{b}$ & $6.83^{c d}$ \\
\hline RF+Control & $0.79 j$ & $0.95^{d}$ & $3.39^{\mathrm{de}}$ & $3.69^{c d e}$ & $2.73^{f}$ & $4.31^{e}$ & $9.44^{f g}$ & $13.67^{\text {ef }}$ & $3.95^{\mathrm{fg}}$ & $6.08^{e f}$ \\
\hline $\begin{array}{l}\text { RF+K-gel } \\
\text { @ } 2.5\end{array}$ & $0.98^{f g}$ & $1.19^{a b}$ & $4.61^{\mathrm{cd}}$ & $4.05^{\mathrm{cd}}$ & $2.99^{e f}$ & $4.00^{f g}$ & $10.06^{f}$ & $13.01^{\mathrm{fg}}$ & $4.53^{\mathrm{e}}$ & $6.20^{\mathrm{ef}}$ \\
\hline $\begin{array}{l}\text { RF+K-gel } \\
\text { @ } 5.0\end{array}$ & $1.14^{\text {de }}$ & $1.10^{\mathrm{b}}$ & $5.62^{a b}$ & $5.07^{a b}$ & $2.44^{\mathrm{fg}}$ & $3.81^{\mathrm{gh}}$ & $9.19^{f}$ & $12.82^{\mathrm{gh}}$ & $4.27^{\mathrm{ef}}$ & $5.85^{f g}$ \\
\hline $\begin{array}{l}\text { RF+P-gel } \\
\text { @ } 2.5 \\
\text { Loading [Mat }\end{array}$ & $1.31^{\mathrm{ab}}$ & $1.22^{\mathrm{a}}$ & $5.24^{\mathrm{b}}$ & $5.01^{a b}$ & $4.24^{\mathrm{a}}$ & $5.08^{a}$ & $14.90^{\mathrm{a}}$ & $14.81^{a}$ & $6.03^{a}$ & $7.33^{a}$ \\
\hline
\end{tabular}


Note: $\mathrm{Fl}$, full irrigation; LI, limited irrigation; RF, rainfed; gel, hydrogel. Means followed by a similar superscript letter within a column are not significantly different (at $\mathrm{P} \leq 0.05$ ) between treatments allowing to least significant difference test.

Table 4. Effect of hydrogels and moisture stress conditions on water productivity (WP) and irrigation water productivity (IWP) in soybean-wheat during 2017-19. Note: Fl, full irrigation; LI, limited irrigation; RF, rainfed. Means followed by a similar superscript letter within a column are not significantly different (at $\mathrm{P} \leq 0.05)$ between treatments allowing to least significant difference test.

\begin{tabular}{|c|c|c|c|c|c|c|c|c|}
\hline \multirow[t]{3}{*}{ Treatment } & \multicolumn{4}{|c|}{ Soybean } & \multicolumn{4}{|l|}{ Wheat } \\
\hline & \multicolumn{2}{|c|}{ WP (kg ha-cm ${ }^{-1}$ ) } & \multicolumn{2}{|c|}{ IWP (kg ha-cm-1) } & \multicolumn{2}{|c|}{ WP (kg ha-cm ${ }^{-1}$ ) } & \multicolumn{2}{|c|}{ IWP (kg ha-cm-1) } \\
\hline & 2017 & 2018 & 2017 & 2018 & 2018 & 2019 & 2018 & 2019 \\
\hline \multicolumn{9}{|l|}{ Irrigation regime (I) } \\
\hline Full irrigation & $21.3^{c}$ & $18.3^{b c}$ & $67.8^{\mathrm{c}}$ & $121.7^{c}$ & $150.2^{c}$ & $176.6^{\mathrm{C}}$ & $169.7^{c}$ & $254.1^{c}$ \\
\hline Limited irrigation & $23.6^{\mathrm{b}}$ & $18.9^{b}$ & $100.9^{b}$ & $232.7^{b}$ & $193.0^{b}$ & $241.8^{\mathrm{b}}$ & $234.7^{b}$ & $454.0^{b}$ \\
\hline Rainfed & $25.8^{a}$ & $19.8^{\mathrm{a}}$ & $194.3^{\mathrm{a}}$ & $1116.5^{\mathrm{a}}$ & $345.9^{a}$ & $312.1^{a}$ & $570.0^{a}$ & $860.0^{a}$ \\
\hline \multicolumn{9}{|c|}{ Hydrogel application $(H)$} \\
\hline Control & $21.0^{\mathrm{C}}$ & $18.7^{b}$ & $101.6^{d}$ & $443.3^{d}$ & $220.6^{b c}$ & $241.4^{b}$ & $312.1^{\mathrm{bc}}$ & $520.5^{b}$ \\
\hline K-hydrogel @ 2.5 & $23.1^{\mathrm{b}}$ & $18.8^{\mathrm{ab}}$ & $117.2^{\mathrm{b}}$ & $508.1^{\mathrm{ab}}$ & $232.5^{\mathrm{ab}}$ & $229.9^{\mathrm{cd}}$ & $330.5^{\mathrm{b}}$ & $490.8^{\mathrm{bc}}$ \\
\hline K-hydrogel @ 5.0 & $20.4^{\mathrm{d}}$ & $18.6^{\mathrm{bc}}$ & $111.5^{\mathrm{C}}$ & $482.4^{\mathrm{bc}}$ & $209.8^{\mathrm{cd}}$ & $235.7^{b c}$ & $293.4^{\mathrm{cd}}$ & $497.5^{\mathrm{cd}}$ \\
\hline P-hydrogel @ 2.5 & $29.7^{a}$ & $20.0^{a}$ & $153.6^{\mathrm{a}}$ & $527.5^{a}$ & $255.8^{a}$ & $266.9^{a}$ & $363.2^{\mathrm{a}}$ & $582.0^{\mathrm{a}}$ \\
\hline \multicolumn{9}{|l|}{ IxHeffect } \\
\hline $\mathrm{FI}+$ Control & $22.5^{\mathrm{d}}$ & $18.6^{\text {de }}$ & $71.6^{\mathrm{ghi}}$ & $123.9^{f}$ & $134.0^{\mathrm{ij}}$ & $167.1^{\mathrm{fg}}$ & $151.3^{g h}$ & $240.5^{f g}$ \\
\hline Fl+K-hydrogel @ 2.5 & $19.1^{\mathrm{e}}$ & $17.8^{\mathrm{ef}}$ & $60.6^{\mathrm{hij}}$ & $118.0^{\mathrm{fg}}$ & $153.2^{\mathrm{ghi}}$ & $176.2^{f}$ & $173.0^{\mathrm{g}}$ & $253.5^{f}$ \\
\hline Fl+K-hydrogel @ 5.0 & $16.3^{\text {ef }}$ & $17.9^{\mathrm{ef}}$ & $51.8^{\mathrm{j}}$ & $119.0^{f}$ & $155.4^{\mathrm{ghi}}$ & $177.6^{f}$ & $175.6^{\mathrm{g}}$ & $255.5^{f}$ \\
\hline Fl+P-hydrogel @ 2.5 & $27.4^{\mathrm{b}}$ & $19.0^{\mathrm{d}}$ & $87.1^{\mathrm{fg}}$ & $125.9^{f}$ & $158.2^{\mathrm{ghi}}$ & $185.6^{f}$ & $178.8^{f}$ & $267.0^{f}$ \\
\hline LI+Control & $22.1^{d}$ & $20.5^{a b c}$ & $94.2^{f}$ & $251.4^{\mathrm{e}}$ & $196.6^{\mathrm{ef}}$ & $244.4^{d}$ & $239.0^{\mathrm{ef}}$ & 459.0 de \\
\hline LI+K-hydrogel @ 2.5 & $27.1^{\mathrm{bc}}$ & $17.4^{\mathrm{ef}}$ & $115.7^{e}$ & $214.0^{\mathrm{e}}$ & $182.0^{\text {efg }}$ & $223.1^{\mathrm{e}}$ & $221.4^{\mathrm{ef}}$ & $418.5^{\mathrm{e}}$ \\
\hline LI+K-hydrogel @ 5.0 & $17.4^{\mathrm{e}}$ & $18.5^{\text {de }}$ & $74.4^{\mathrm{gh}}$ & $227.0^{\mathrm{e}}$ & $177.5^{\text {efgh }}$ & $252.9^{d}$ & $215.8^{\mathrm{ef}}$ & $474.8^{d}$ \\
\hline LI+P-hydrogel @ 2.5 & $27.9^{b}$ & $19.4^{\mathrm{cd}}$ & $119.0^{\mathrm{e}}$ & $238.4^{\mathrm{e}}$ & $216.0^{\mathrm{e}}$ & $246.5^{d}$ & $262.6^{\mathrm{e}}$ & $463.0^{\text {de }}$ \\
\hline $\mathrm{RF}+$ Control & $18.4^{\mathrm{e}}$ & $16.9^{\mathrm{fg}}$ & $138.9^{d}$ & $954.7^{d}$ & $331.4^{\mathrm{bc}}$ & $312.8^{a}$ & $546.1^{\mathrm{bc}}$ & $862.9^{a}$ \\
\hline RF+K-hydrogel @ 2.5 & $23.2^{d}$ & $21.1^{\mathrm{ab}}$ & $175.3^{c}$ & $1192.3^{a b}$ & $362.3^{\mathrm{ab}}$ & $290.3^{b c}$ & $597.1^{\mathrm{ab}}$ & $800.0^{\mathrm{bc}}$ \\
\hline RF+K-hydrogel @ 5.0 & $27.6^{b}$ & $19.5^{\mathrm{cd}}$ & $208.3^{b}$ & $1101.1^{\mathrm{c}}$ & $296.5^{\mathrm{cd}}$ & $276.5^{\mathrm{C}}$ & $488.7^{\mathrm{cd}}$ & $762.2^{\mathrm{c}}$ \\
\hline RF+P-hydrogel @ 2.5 & $33.8^{a}$ & $21.6^{a}$ & $254.6^{a}$ & $1218.1^{a}$ & $393.3^{a}$ & $368.7^{a b}$ & $648.2^{a}$ & $1016.1^{b}$ \\
\hline
\end{tabular}


Table 5. Effect of hydrogels and moisture stress conditions on economics of soybean and wheat production in 2018-19. 


\begin{tabular}{|c|c|c|c|c|c|c|c|c|}
\hline \multirow[t]{3}{*}{ Treatment } & \multicolumn{4}{|l|}{ Soybean } & \multicolumn{4}{|l|}{ Wheat } \\
\hline & $\begin{array}{l}\text { Cost of } \\
\text { production }\end{array}$ & $\begin{array}{l}\text { Gross } \\
\text { profitability }\end{array}$ & $\begin{array}{l}\text { Net } \\
\text { profitability }\end{array}$ & $\mathrm{B}: \mathrm{C}$ & $\begin{array}{l}\text { Cost of } \\
\text { production }\end{array}$ & $\begin{array}{l}\text { Gross } \\
\text { returns }\end{array}$ & $\begin{array}{l}\text { Net } \\
\text { returns }\end{array}$ & $\mathrm{B}: \mathrm{C}$ \\
\hline & $($ US\$ ha-1) & $($ US\$ ha-1) & $($ US\$ ha-1) & & $\left(U S \$ h^{-1}\right)$ & $\begin{array}{l}\text { (US\$ ha- } \\
\left.{ }^{1}\right)\end{array}$ & $\begin{array}{l}\text { (US\$ } \\
\left.\mathrm{ha}^{-1}\right)\end{array}$ & \\
\hline \multicolumn{9}{|c|}{ Irrigation regime (I) } \\
\hline $\begin{array}{l}\text { Full } \\
\text { irrigation }\end{array}$ & $377.3^{\mathrm{a}}$ & $608.1^{a}$ & $230.7^{a}$ & $1.62^{\mathrm{a}}$ & $570.6^{a}$ & $1359.4^{\mathrm{a}}$ & $788.8^{a}$ & $2.38^{a}$ \\
\hline $\begin{array}{l}\text { Limited } \\
\text { irrigation }\end{array}$ & $364.3^{a}$ & $582.6^{b}$ & $218.3^{a b}$ & $1.61^{\mathrm{a}}$ & $544.4^{\mathrm{a}}$ & $1216.3^{b}$ & $671.9^{b}$ & $2.24^{b}$ \\
\hline Rainfed & $351.2^{\mathrm{a}}$ & $558.0^{c}$ & $206.8^{b c}$ & $1.59^{a}$ & $518.2^{a}$ & $1096.3^{c}$ & $578.1^{c}$ & $2.12^{c}$ \\
\hline \multicolumn{9}{|c|}{ Hydrogel application (H) } \\
\hline Control & $333.9^{a}$ & $575.3^{b}$ & $241.4^{a b}$ & $1.72^{\mathrm{a}}$ & $514.0^{\mathrm{a}}$ & $1224.7^{\mathrm{ab}}$ & $710.7^{a b}$ & $2.38^{a}$ \\
\hline $\begin{array}{l}\text { K-hydrogel } \\
\text { @ } 2.5\end{array}$ & $363.8^{\mathrm{a}}$ & $571.9^{b c}$ & $208.1^{c}$ & $1.57^{\mathrm{bc}}$ & $544.0^{\mathrm{a}}$ & $1185.1^{\mathrm{bc}}$ & $641.1^{b c}$ & $2.17^{b}$ \\
\hline $\begin{array}{l}\text { K-hydrogel } \\
\text { @ } 5.0\end{array}$ & $393.7^{a}$ & $573.0^{\mathrm{b}}$ & $179.3^{\mathrm{cd}}$ & $1.46^{\mathrm{d}}$ & $573.9^{a}$ & $1219.7^{b}$ & $645.8^{b}$ & $2.12^{b c}$ \\
\hline $\begin{array}{l}\text { P-hydrogel } \\
\text { @ } 2.5\end{array}$ & $365.6^{a}$ & $611.4^{\mathrm{a}}$ & $245.8^{a}$ & $1.67^{a b}$ & $545.7^{a}$ & $1266.5^{\mathrm{a}}$ & $720.8^{a}$ & $2.32^{\mathrm{ab}}$ \\
\hline \multicolumn{9}{|l|}{ Ix H effect } \\
\hline $\mathrm{Fl}+$ Control & $347.0^{\mathrm{a}}$ & $621.3^{a b}$ & $274.3^{a b}$ & $1.79^{a b}$ & $540.2^{a}$ & $1285.8^{\mathrm{bc}}$ & $745.6^{b c}$ & $2.38^{a b}$ \\
\hline $\begin{array}{l}\text { Fl+K- } \\
\text { hydrogel @ } \\
2.5\end{array}$ & $376.9^{a}$ & $587.5^{\mathrm{bcd}}$ & $210.6^{\text {cde }}$ & $1.56^{\text {def }}$ & $570.1^{a}$ & $1357.3^{a b}$ & $787.1^{a b}$ & $2.38^{a b}$ \\
\hline $\begin{array}{l}\text { Fl+K- } \\
\text { hydrogel @ } \\
5.0\end{array}$ & $406.8^{a}$ & $594.4^{\mathrm{ab}}$ & $187.5^{\mathrm{de}}$ & $1.46^{\mathrm{ef}}$ & $600.1^{a}$ & $1365.9^{a b}$ & $765.8^{a b}$ & $2.28^{a b c}$ \\
\hline $\begin{array}{l}\text { Fl+P- } \\
\text { hydrogel @ } \\
2.5\end{array}$ & $378.7^{a}$ & $629.1^{a}$ & $250.4^{b c}$ & $1.66^{\mathrm{cd}}$ & $571.9^{a}$ & $1428.7^{a}$ & $856.8^{a}$ & $2.50^{a}$ \\
\hline LI+Control & $333.9^{a}$ & $628.2^{\mathrm{ab}}$ & $294.3^{a}$ & $1.88^{a}$ & $514.0^{a}$ & $1231.6^{\text {cde }}$ & $717.6^{b c}$ & $2.40^{\mathrm{ab}}$ \\
\hline $\begin{array}{l}\text { LI+K- } \\
\text { hydrogel @ } \\
2.5\end{array}$ & $363.8^{a}$ & $537.3^{\text {ef }}$ & $173.5^{\text {ef }}$ & $1.48^{\mathrm{ef}}$ & $544.0^{a}$ & $1124.7^{f}$ & $580.7^{e}$ & $2.07^{d}$ \\
\hline $\begin{array}{l}\text { LI+K- } \\
\text { hydrogel @ } \\
5.0\end{array}$ & $393.7^{a}$ & $569.6^{d}$ & $175.8^{\text {ef }}$ & $1.45^{f}$ & $573.9^{a}$ & $1269.5^{c}$ & $695.6^{b c}$ & $2.21^{\mathrm{bcd}}$ \\
\hline $\begin{array}{l}\text { LI+P- } \\
\text { hydrogel @ } \\
2.5\end{array}$ & $365.6^{a}$ & $595.2^{\mathrm{ab}}$ & $229.6^{\mathrm{cd}}$ & $1.63^{\text {cde }}$ & $545.7^{a}$ & $1239.2^{\mathrm{cd}}$ & $693.5^{\mathrm{cd}}$ & $2.27^{\mathrm{bcd}}$ \\
\hline RF+Control & $320.8^{a}$ & $476.3^{g}$ & $155.5^{f g}$ & $1.48^{f g}$ & $487.9^{a}$ & $1156.7^{\text {def }}$ & $668.8^{\mathrm{cd}}$ & $2.37^{a b}$ \\
\hline $\begin{array}{l}\text { RF+K- } \\
\text { hvdrncel } \Omega\end{array}$ & $350.7^{a}$ & $590.9^{b c}$ & $240.1^{b c}$ & $1.68^{b c}$ & $517.8^{a}$ & $1073.3^{f}$ & $555.5^{e f}$ & $2.07^{d}$ \\
\hline
\end{tabular}




\begin{tabular}{|lllllllll|}
\hline $\begin{array}{l}\text { RF+K- } \\
\text { hydrogel @ } \\
5.0\end{array}$ & $380.7^{\mathrm{a}}$ & $555.1^{\text {de }}$ & $174.4^{\text {ef }}$ & $1.46^{\text {ef }}$ & $547.7^{\mathrm{a}}$ & $1023.8^{\mathrm{g}}$ & $476.0^{\mathrm{fg}}$ & $1.87^{\mathrm{e}}$ \\
\hline $\begin{array}{l}\text { RF+P- } \\
\text { hydrogel @ } \\
2.5\end{array}$ & $352.5^{\mathrm{a}}$ & $609.8^{\mathrm{abc}}$ & $257.3^{\mathrm{bc}}$ & $1.73^{\mathrm{bc}}$ & $519.6^{\mathrm{a}}$ & $1131.7^{\mathrm{f}}$ & $612.1^{\mathrm{de}}$ & $2.18^{\mathrm{cd}}$ \\
\hline
\end{tabular}

Note: Fl, full irrigation; LI, limited irrigation; RF, rainfed; B:C, benefit: cost. Means followed by a similar superscript letter within a column are not significantly different (at $\mathrm{P} \leq 0.05)$ between treatments allowing to least significant difference test.

\section{Figures}
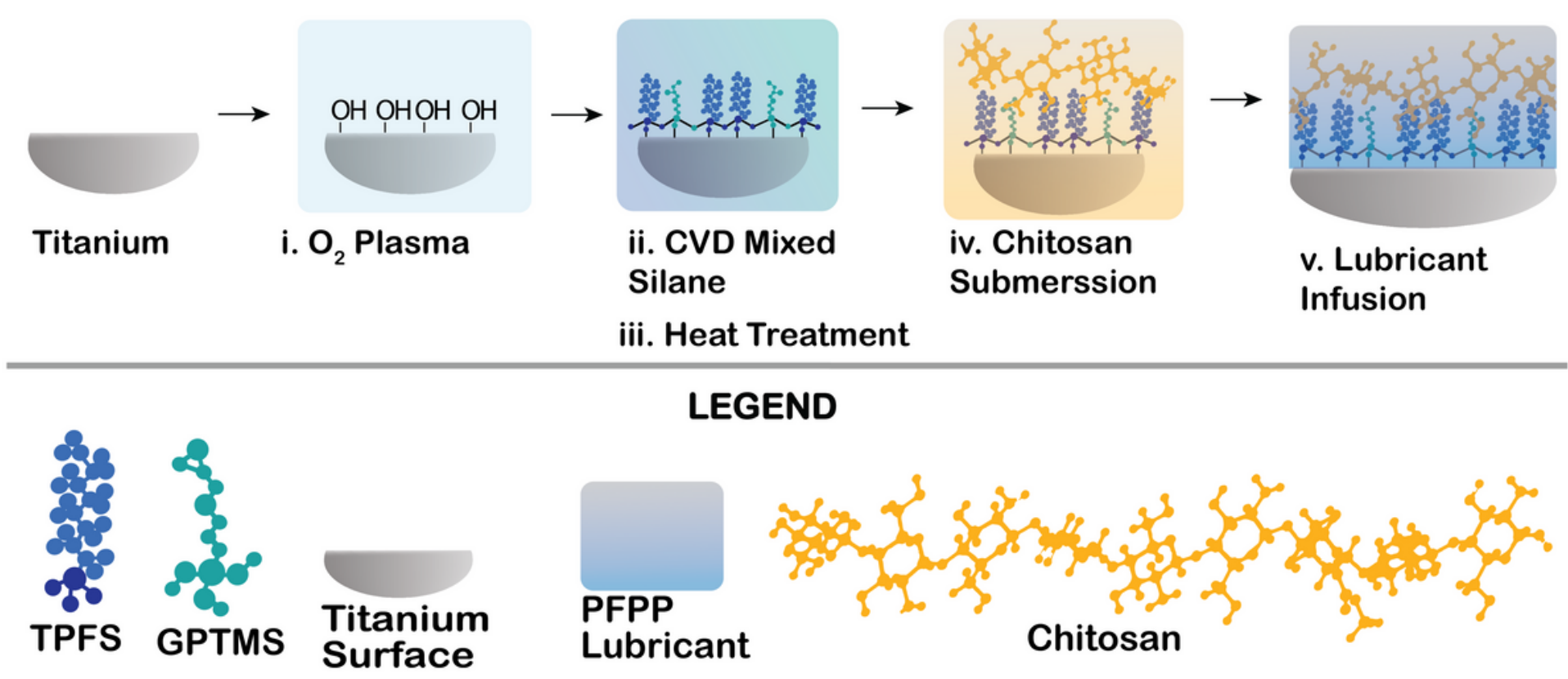

\section{LEGEND}

Figure 1

Fabrication schematic. Schematic representation of the fabrication process for the chitosan conjugated liquid-infused coating on titanium. 

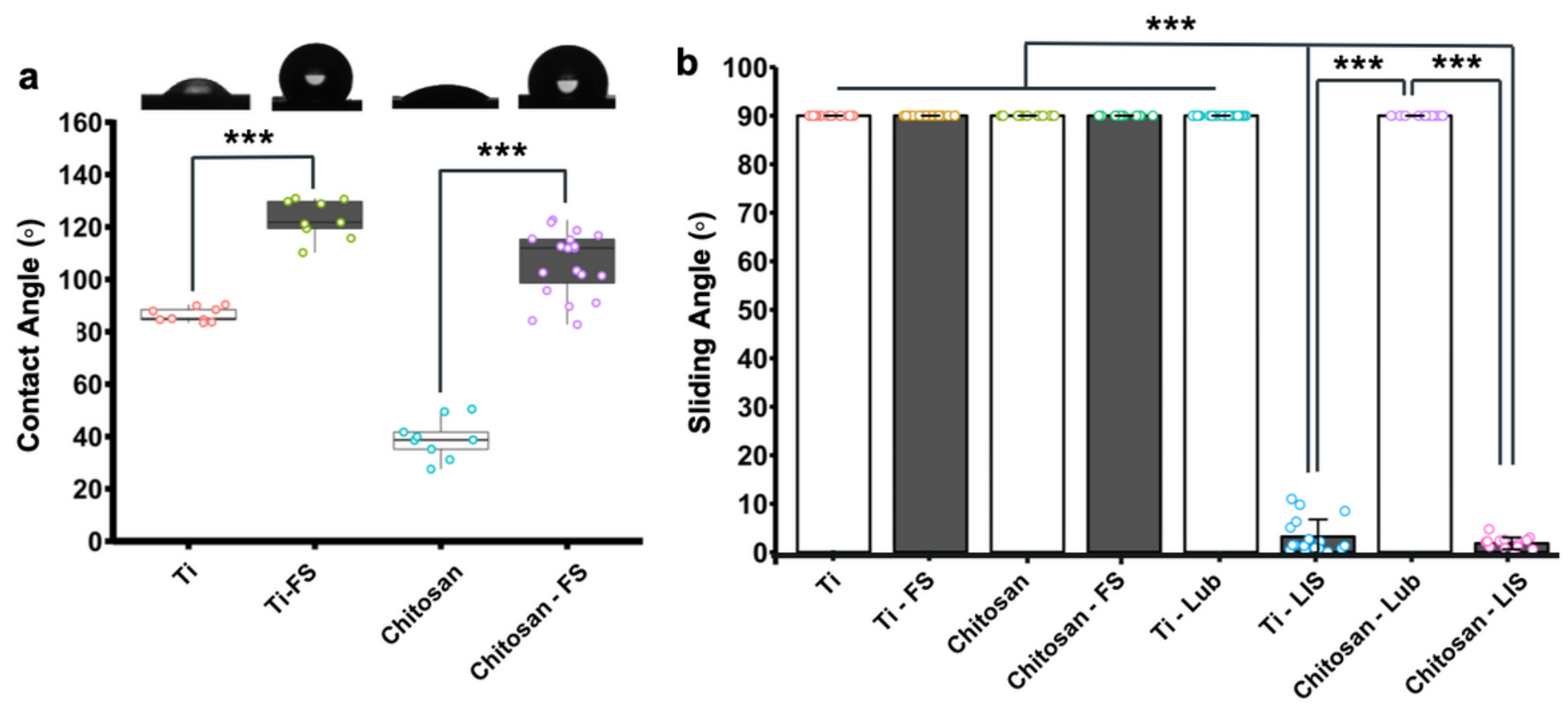

Figure 2

Surface Characterization. (a) Water static contact angle measurements on titanium and titanium coated surfaces. The morphology of the water droplet on each surface is shown on top of each bar. (b) Water sliding angle for the coated titanium surfaces, both bare or lubricated with PFPP. Each group had a minimum of three samples tested, and each sample was measured a minimum of three times. Data represent the mean of five replicates and error bars show standard deviation. '***' represent a p-value of $\mathrm{P}<0.001$.

a

3 Days

7 Days
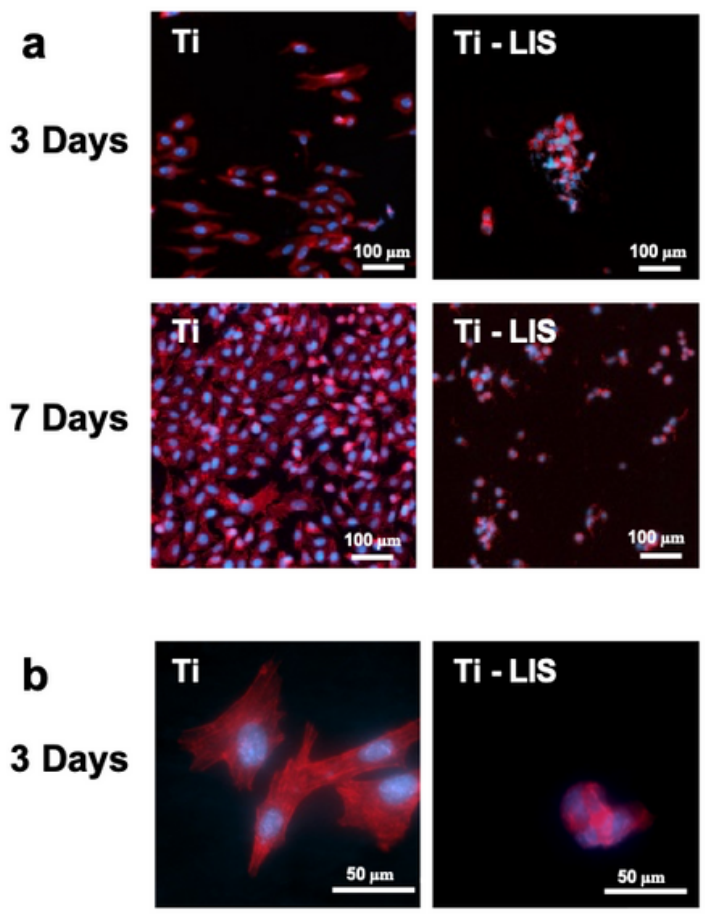
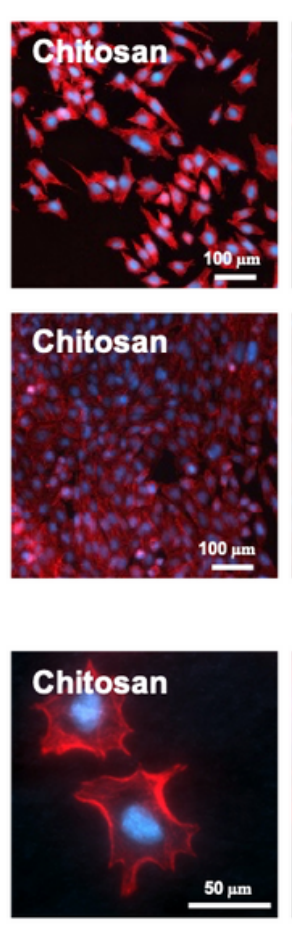
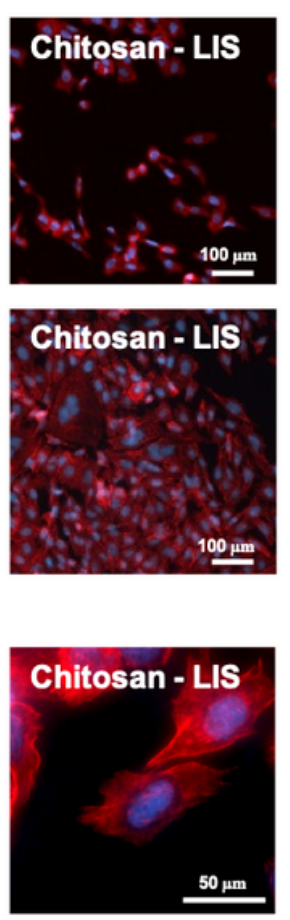
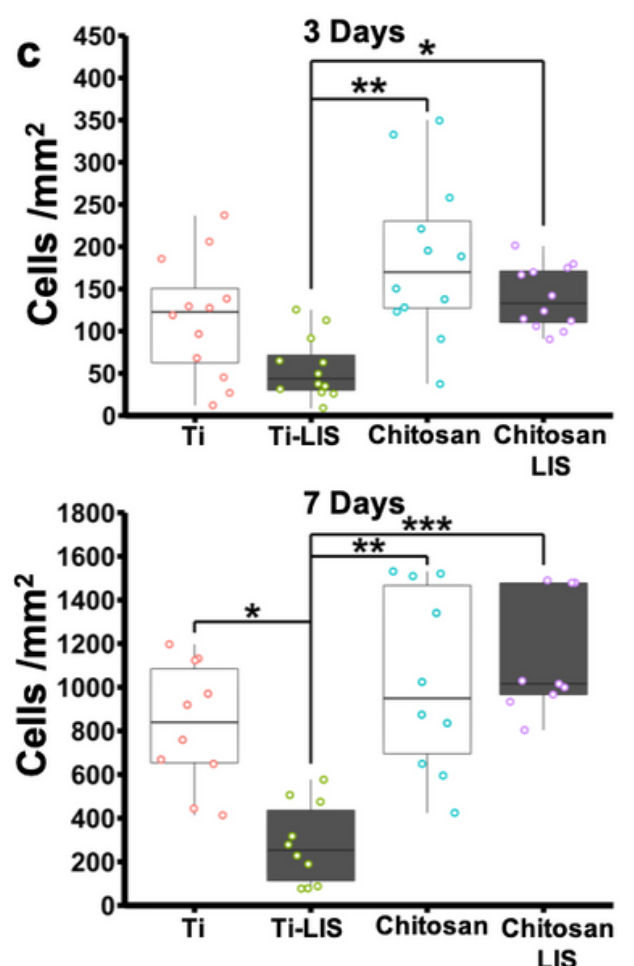

Figure 3 
SaOS-2 Cell Proliferation After Three- and Seven-day Cell Cultures. (a) Representative fluorescence microscopy images (nuclei: blue; microfilaments: red) displaying the density and distribution of adherent cells on titanium and titanium treated surfaces. (b) Representative fluorescence microscopy images (nuclei: blue; microfilaments: red) displaying the morphology of the cells on titanium and titanium coated surfaces. (c) Number of adherent cells on control and treated titanium surfaces after three- and seven-day cell cultures. Error bars represent the standard deviation for at least three samples per group. Statistical significance annotation is shown as ' $*$ ' for $\mathrm{P}<0.05$, '**' for $\mathrm{P}<0.01$ and ' $* \star *$ ' for $\mathrm{P}<0.001$.

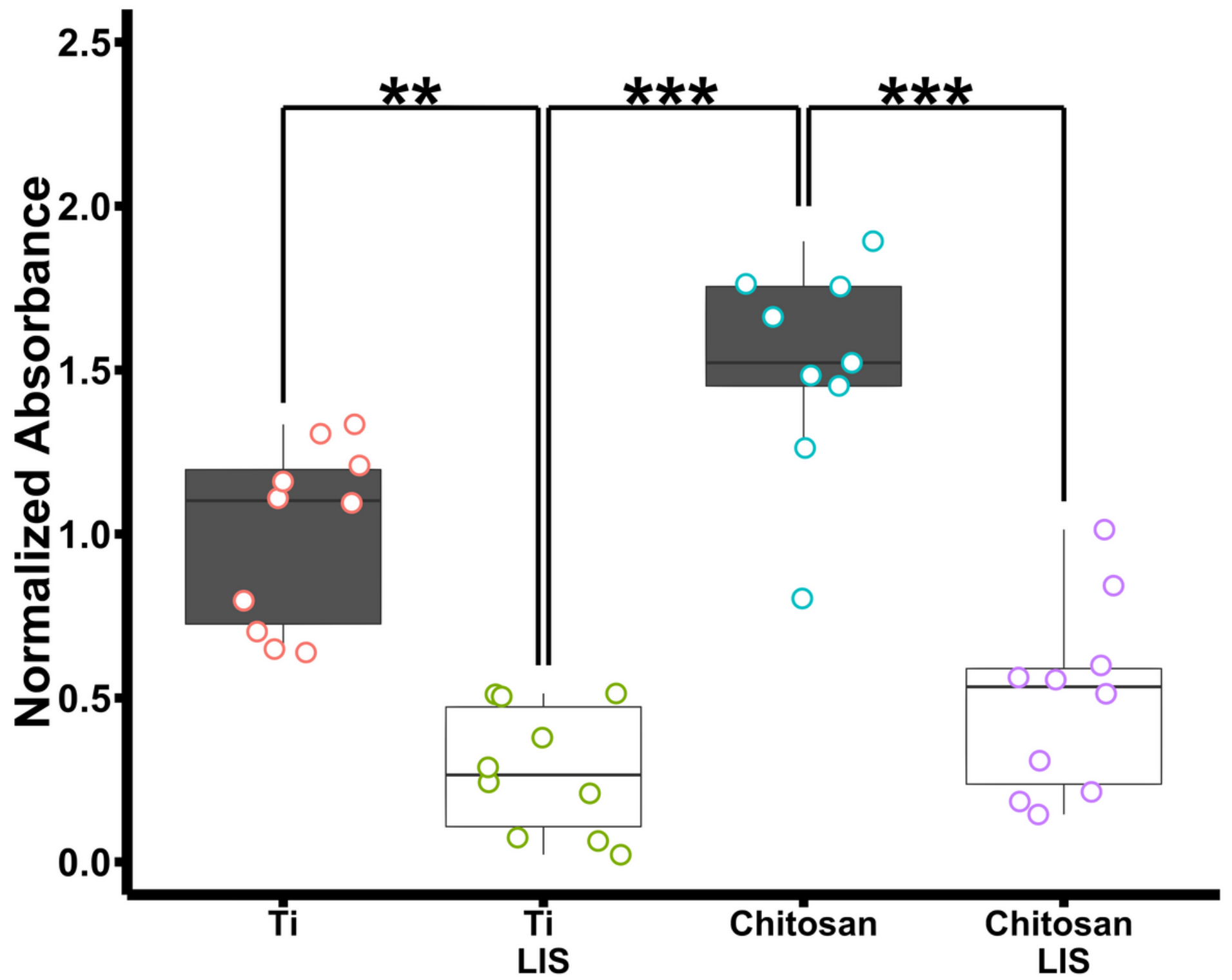

Figure 4

Crystal Violet Evaluation of S. aureus Biofilm Formation. Normalized crystal violet absorbance after biofilm growth using MRSA MW2 strain on titanium (Ti), liquid-infused titanium (Ti-LIS), chitosan conjugated titanium (Chitosan), and biofunctional chitosan liquid-infused titanium (Chitosan-LIS). Whiskers span the first quartile and fourth quartile range of at least 3 samples. Statistical significance annotation is shown as ' $*$ ' for $P<0.05$, '**' for $P<0.01$ and '***' for $P<0.001$. 